\title{
Zakat as an Instrument of Eradicating Poverty (Indonesian Case)
}

\author{
M. Anton Athoillah ${ }^{1}$ \\ ${ }^{1}$ Sharia and Law Faculty, UIN Sunan Gunung Djati Bandung. \\ E-Mail: kafabil@yahoo.com
}

\begin{abstract}
This paper describes more clearly about the charity as an instrument of poverty alleviation. Said to be more pronounced because zakat is not only described from the aspect of Islamic law, but also from the aspect of Islamic Economics. Starting from the idea of a content analysis of two professors of Economic Development, Prahalad and Yuyun Wirasasmita, this paper reveals the fundamental aspects of the causes of poverty, namely culture, alienation and exploitation. In this paper, the charity manages to pack in a comprehensive manner to a complementary instrument, whether Islamic law, and even Islamic Economics. Among the novelties in this paper is a substantive interpretation of zakat which is connected with the theory of economic development, comparated with tax and economic-mathematical analysis to find a charity to further its position in the study of economics. As for other things that were outlined in this paper is the normative aspects of zakat, as where explicit, as an instrument of poverty alleviation for various sectors, as seen from its usability goals.
\end{abstract}

Keyword: zakat, poverty, cultural alienation, exploitation, utilization

\section{A. INTRODUCTION}

When Prahalad proposes his idea that the unfortunate people are not viewed as the victim (of economic injustice) or burden (Discussing on poverty as global economic burden could be seen in Mudrajat Kuncoro) in the process of economic development; rather they should be perceived as powerful entrepreneur and have considerations to elevate their own welfare (Prahalad 2005), the first question raised is, "how could such idea as Prahalad's be performed?"

As mentioned by Wirasasmita, that there are three main causes of poverty in a state: poverty culture, alienated condition, and exploitation. Connected to Prahalad's idea as mentioned above, "poverty culture" is the main cause why it is hard to perform such idea. The unfortunate, in their daily life, are trapped in the culture of poverty. So, they do not make some efforts, they are totally surrendered, stumped, and accept "what it is" and "what happen" in their life.

To change such poverty culture, said Wirasasmita, begins with education, which in this case is moral education. Such is because that something moral is something originated from faith or belief. This system produces values and finally culture. It is culture that accompanying the life course of somebody, and of course it could influence any decision taken in his mundane life (Wirasasmita 2010). To make the explanation clear, here is a chart for simplification (Nasution 1995 and Nasution 1990): 
Chart-1

Elements and Kinds of Culture

\begin{tabular}{|c|c|c|c|c|c|}
\hline $\begin{array}{r}\text { Elements of } \\
\text { Culture }\end{array}$ & $\begin{array}{c}\text { System of } \\
\text { Faith }\end{array}$ & Values & $\begin{array}{c}\text { World- } \\
\text { View }\end{array}$ & $\begin{array}{c}\text { Example of } \\
\text { World-View }\end{array}$ & Consequence \\
\hline Pessimistic & Fatalistic & $\begin{array}{c}\text { Destiny Could Not } \\
\text { Be Changed }\end{array}$ & Static & $\begin{array}{c}\text { Property } \\
\text { Destined By } \\
\text { God }\end{array}$ & $\begin{array}{c}\text { Surrender, } \\
\text { Predestinated }\end{array}$ \\
\hline Optimistic & Rationalistic & $\begin{array}{c}\text { Destiny Could Be } \\
\text { Changed (Q.S. Al- } \\
\text { Ra'd: 11) }\end{array}$ & Dynamic & $\begin{array}{c}\text { Property Should } \\
\text { Be Achieved }\end{array}$ & Will To Do \\
\hline
\end{tabular}

Explanation:

- $\quad$ People who have pessimistic kind of culture have a fatalistic system of faith, values of life connected to their destiny could not be changed; so that their way of life is static, and they are totally surrendered; accept what it is -what happened to them. An example of their view of life is that "Property is divinely corrected".

- $\quad$ People who live in the optimistic kind of culture. They believe in rationalistic system, that life connected to their destiny could be changed, so that their world-view is dynamic, and they would as maximum as possible elevate their quality of life. An example of this way of thought is that, "Property should be found by ourselves, for God only gives the guidance on how seek the property."

Before discussing Prahalad's idea, it is better if we reexamine vicious cycle leading to poverty for most of population of the Earth. As mentioned by Nurske, Meier, and Baldwin in Jhingan, developing countries are generally stuck in something called "vicious cycle of poverty".

Figure-1

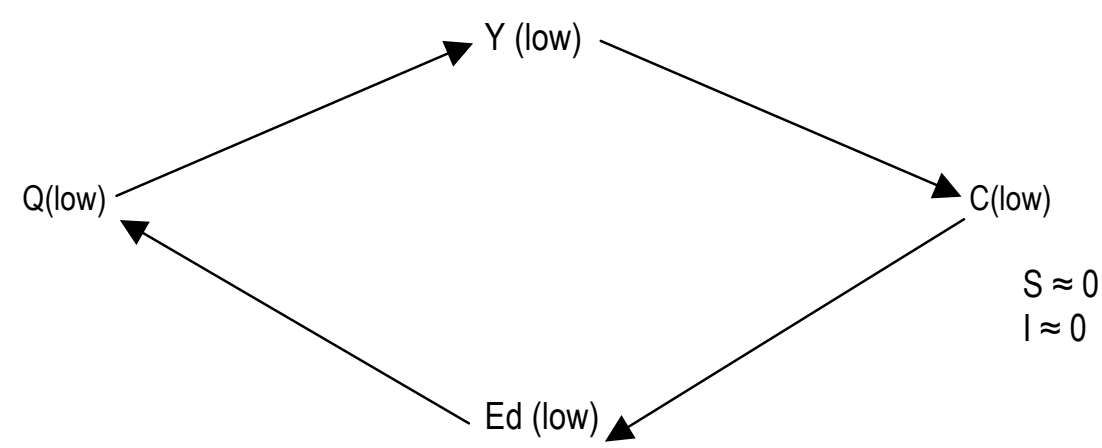

Explanation: Because of the Income is low, so the Consumption is low, Education is also low, and therefore Productivity is low (no Savings equals no Investment).

This poverty trap (Smith 2006) basically comes from the fact that total productivity in developing countries is resulted from the lack of capital, imperfect market, and economic backwards. In short, poverty and economic backwards are synonymous terms. A country becomes poor because of it is backwards; and it becomes backwards because it is poor. Developing countries are constantly poor and backwards because they have no resources to elevate development (Jhingan 2007). 
If a country elevate has its resources, so the above figure changed to:

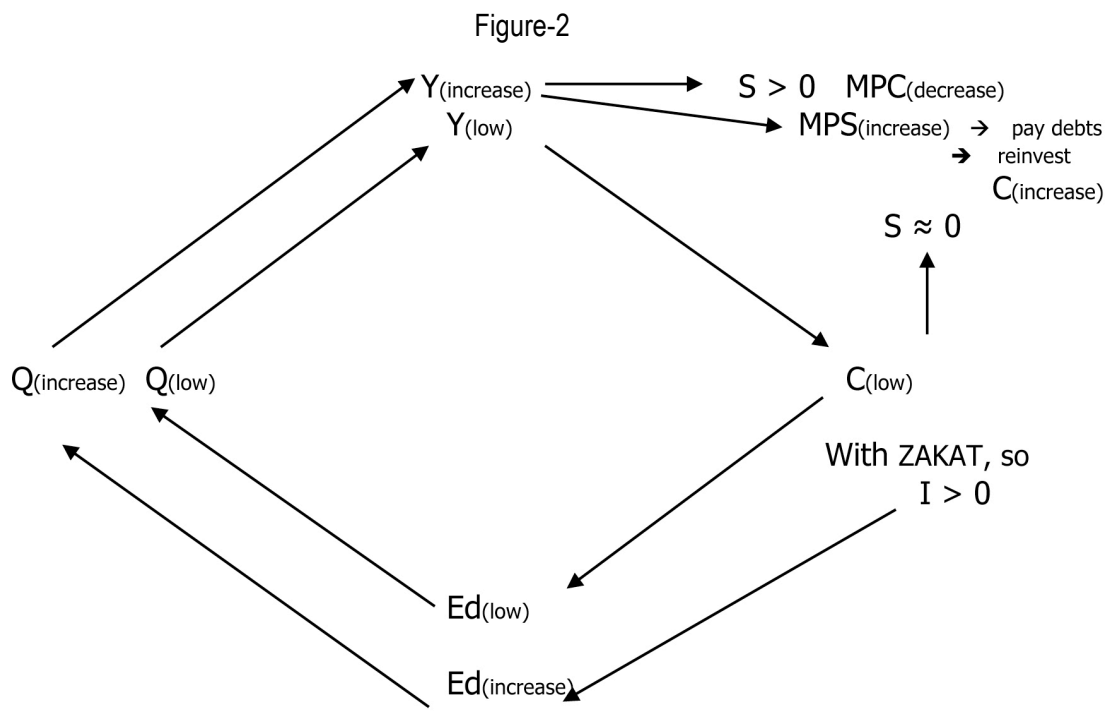

Explanation:

In the first condition owing to that the Income is low, the Consumption is also low. But, with zakat, there is investment. Education as a part of investment increased. Therefore, because of the education, the productivity is also increased. Such thing brings about the increase of income, consumption, and that savings becomes $\gg>0$. The country can pay its debts and do reinvestment.

In a more complete figure, it can be seen as follow:

Figure-3

Zakat as an Instrument of Eradicating Poverty

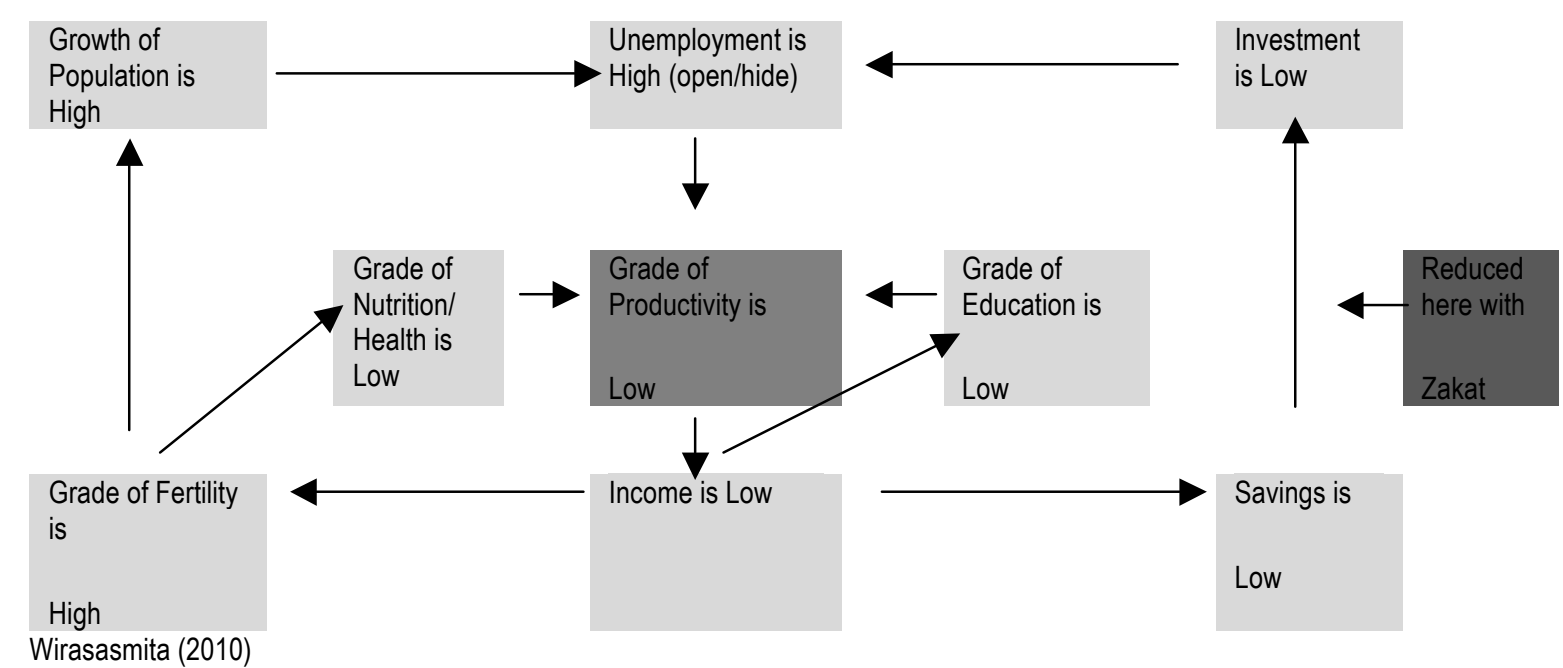

\section{B. METHODOLOGY}

This research used case study methods with literature study by examining a variety of journals and books related wirh economic development. this paper is a substantive interpretation of zakat which is connected with the theory of economic development, comparated with tax and economicmathematical analysis to find a charity to further its position in the study of economics. As for other things that were outlined in this paper is the normative aspects of zakat, as where explicit, as an 
instrument of poverty alleviation for various sectors, as seen from its usability goals. Also, the method used in this study is a survey research, using the approach verificative explanatory research and causality testing. Purpose of explanatory research is to know and explain "why" something happened, whereas causality verification testing is research that explains the causal relationship between the study variables through testing hypothesis. ${ }^{1}$

\section{RESULT AND DISCUSSION}

\section{Between Tax and Zakat}

Stiglitz argued that the levies, existing since ancient times, even if charges in the past with the present is different. In the initial discussion of the tax (taxation), Stiglitz said that taxation has existed since the existence of the State and its organized government (government organized). Stiglitz connecting the initial explanation to the concept of tithe in the Bible. According to him, as it says in the Bible, tithe (tithe, or tenth) of the plant should be set aside for the purpose of redistribution and assistance to the pastor. Charges in the past referred to as the feudal Levie, while in modern times now referred to as taxes (Stiglitz 2000).

According to Pigou in Suprayitno (Suprayitno 2005), modern taxes are connected to public goods. It means that how far that society could be 'forced' to pay taxes depends on how big the satisfaction of society to the existence of facilities funded by the tax. This Pigou's theory was completed by Bowen, Lindhal, and Samuelson. They say the same thing: connecting government's expenses to the tax. Through the tax the government is not only collecting funds, but also creating public goods satisfying the citizens. Therefore, the tax has two dimensions: (1) providing funds, and (2) transforming the burden of the tax to the public goods in order to satisfy the society.

In Indonesia, zakat has only fulfilled the first dimension (Suprayitno 2005). For the potentials and the realizations of zakat collection per year are only more or less USD 70 billions. There should be more in numbers, since the majority of Indonesians are Muslims. But there are some things to discern.

Firstly, zakat is only taken from certain things such as money, agriculture, farming, and trade. Even though it is extended to such other things as deposits, house, or income, the items are not as much as the tax. It is because that the tax is channelized through government's legalization to all economic streams either in production, consumption, or distribution. On the other hand, there is also possibility of increasing zakat acceptance because of the combination of zakat of income or zakat of profession, where there are two components should be noticed here, that is how much of the income should be zakat-ized, analogue to the zakat of agriculture. Zakat of agriculture should be paid every harvest. Therefore, profession is illustrated as agricultural business, where the professionals have the harvest when they accept wages. Here, every time the wages paid there should be zakat in it. The other component is that the wages which should be zakat-ized (the gross), that is, "a take home pay" before being used to fulfill consumptive needs.

Secondly, zakat could not be used arbitrarily for public interests. Zakat, for today, is restricted only for the Muslim interests. It is only the Muslims who believe in the zakat doctrine. And even in the Muslim circles, there are only eight asnaf (groups) who can receive zakat: the destitute, the poor, the slaves, the people working in the zakat affair (amilun), the people burdened by debts, the people who in the ways of searching knowledge and those who drain their money in the travel, 
those who newly embrace Islam and that their hearts are still weak, and those who fight for Islam. Here it is that Islam secures the life of the destitute and the poor (In Islamic economics, giving some of their wealth to the needy is not only generosity, it is the rights of the poor).

In order that zakat plays a significant role, some Muslim economists suggest that this zakat should be a permanent supplement of income for those who are not able to achieve enough income by their only ways. Zakat could also be used to provide trainings and capitals for "excellencies," either being as a free-interest credit card or as a kind of aid, to make them able to build their own small enterprises in order to be independent (Suprayitno 2005). This is the one in line with Prahalad's idea (Prahalad 2007).

Some writers also advocate the idea that zakat could be used as countercyclical tool by not to spread all its products to a booming period in order to save the surplus so that could be used in the time of recession. Also, by this, it could be noticed that they are who have rights to receive zakat have their own fair share.

Zakat is an independent social security tool appointing the rich having a moral duty to help the poor and neglected to help themselves by all means of social security schemes, so that destitution and poverty could be diminished in the Muslim society (Suprayitno 2005). In an emergency condition, zakat could be performed as a first aid, so that the (Muslim) poor community could be the Bottom of Pyramid (BOP) of consumers, and in a normal condition, zakat could be an injection in order to make them BOP of entrepreneur (Prahalad 2007) (muzakki=potential zakat payers).

Nevertheless, zakat does not wipe out government's duty to create prosperity, except only to help to share some of the government's responsibility to the society, especially close relatives and neighbors of the connected individuals, so that reduce the burden of the government. It is unrealistic to expect to the government to weigh all prosperity burdens. If the zakat is not enough, Muslim jurists (fuqaha) advise that Muslim community should weigh this burden and attempt to find other ways and tools to reach such economic goal. Here, Prahalad's idea on the roles of civil society organization could be applied.

To this, zakat should not be distributed to fulfill consumption of basic needs drained day by day. Although it could help the destitute-the poor to fulfill their own urgent needs, the way of using zakat as this is inclining to ignore the receivers in their own situation of destituteness. Giving "the fish" all the time does not urge people to be "fishermen" especially when zakat is spread by "flat rate" basis. Therefore, "reorientation" of priority of zakat usage should be done to its long-term usage. Firstly, zakat should be distributed as "negative income tax" to maintain incentive of work or to seek income in the poor circles by their own ways. Secondly, some of collected zakat (as much as $50 \%$ ) should be used to finance the activity of giving "fishhook" (productive activities) to the groups of the destitute-poor (Suprayitno 2005).

Furthermore, it is mentioned that the main goal of "giving fishhook activities" is to increase the abilities of the destitute-poor people to create income and elevate themselves from poverty. For this goal zakat could be used as financing various productive skill trainings, giving capital aid to work or giving start-up capitals. Rather than giving consumptive aid to five families in a month, for instance, it is better that those funds are combined and used in a productive enterprise for those five families. It is already an example of what is the meaning of "economic development and social transformation" in Prahalad's terms (Prahalad 2007). 
Another thing from this attempt to diminish poverty -meant as an attempt to full out the poor from their own poverty-is fisabilillah, for the way of Allah. In the warfare, fisabilillah means prioritizing jihad physically. In the peace, it means 'all activities useful for the Muslim community (ummah)' or 'any attempt to eradicate infidelity and run Allah's will'. Because that poverty could trap people to be infidels, pulling out the poor from their poverty is also a fisabilillah enterprise. The usage of zakat for productive activities could be legitimized here (Suprayitno 2005).

Zakat allocation should not be restricted only for short-term usage. Most Muslim writers are in the position of emphasizing efforts to help the destitute and poor by giving them means of production either by money, skills, trainings, and jobs in order that they can elevate their incomes in line with giving them various short-term consumption to support working, public transports, housings, etc. It is mentioned that there is no special requirements for distributing zakat by cash, and there is no requirements that it should be in such consumptive goods as food or that zakat should be in a direct distribution in the means of goods or services. The only restriction should be known by everyone is that zakat is performed because one has over condition of minimum grade of being released (from zakat payment), requiring that those who could afford zakat do not allowed to receive it. The minimum free from zakat is expressed in the meaning of availability or that the wealth is belonged more than one year.

Zakat raises the income of the poor. Because of their low income, such supplement of income would only use for purchasing basic goods and services, so that elevating aggregate demand for basic goods and services. The increase of this aggregate demand would attract the increase of investments. On the other hand, zakat aggregately also urge the raise of savings and investments (Suprayitno 2005).

Besides urging investments and preventing accumulation of wealth, zakat also appeals to activity of purchasing consumptive goods, whether from the receiver or the giver. Therefore, the stream of capital from the two channels, i.e. investments and purchasing, would push for creating working opportunity for millions of people, and in line with that, pioneering the acceleration of income growth.

Zakat is a special "tax" (payment) levied from one's net wealth, which should be collected by the state and used for special purposes, especially for various social security programs. Government's routine expenses are not to be fulfilled by this zakat fund. Zakat is in all kinds of wealth including savings which is annually increased, which (if it is counted) since the beginning of the year exceed the minimum of compulsive wealth to be zakat-ized (nisab). It is levied from the net wealth by the percentage determined (by Islam) if that wealth has already exceeded the determined minimum limit, and could be paid in the end of the year.

Zakat as written in the Q.s. Al-Taubah verse 103 contains the meaning that every Muslim who has already exceed the nisab should compulsively clean their wealth by giving some of their wealth to those who have the rights. Here, then, according to Al-Shawkani, zakat linguistically has double meaning of "growth" and "purification" (Al-Syawkani 2007).

These characteristics give an important role to zakat in Islamic System of Macro-economics. It is levied from net wealth, either to be used in productive activities, stored, or even used in extravagant life. Hence, zakat could control such following things:

a. Allocation of productive wealth in various alternative usages.

b. Unproductive means of production. 
c. Allocation of income in between the expenses and savings.

d. Allocation of savings in between productive usages and luxury goods, which finally damaged without any usage.

Zakat renovate the patterns of consumption, production, and distribution in Muslim society. One of the biggest evil in the system of capitalism is mastery and possession of productive resources controlled by certain fortunate people, so that ignoring the unfortunate which are many more than the fortunate one. It affects the difference in the existing income and finally could slower industrial growth and domestic commerce. For an economic order dominated by monopoly always prevents the usage of economic resources. It is criticized badly by Prahalad on capitalism. Zakat is a compulsory tax for Muslim rich circles, aiming at eradicating blatant differences of income and regaining the consumptive power of the poor. According to the Qur'anic doctrines it is not wrong if one attempts to gain money, but the duty of Islamic state is how that there is no one of its citizen ignored to get the simplest, basic needs (Suprayitno 2005).

This goal could be achieved easily by distributing zakat appropriately in the poor and unfortunate circles. By giving them the power of purchasing, zakat could create a balance between supply and demand of goods, therefore, easing the ways of production and paving the way of improvement, elevating redistribution of income and national prosperity. Hence, zakat winning the rich and the poor as well, the giver as well as the receiver. As mentioned by the Qur'an, "zakat brings prosperity either for the payer or for the receiver". If it is exist, "a whole new world opportunity will open up," as said by Prahalad.

To reconstruct, zakat is not an aim but a tool to reach the aim itself. So, the essence of zakat is not in the detail requirements, but in the goal and target being planned. But we should be aware that the bigger Islamic influence to the people, the bigger the opportunity to collect zakat and that its distribution could also run efficiently, besides the possibility to avoid the payment would also be difficult. So, Muslim countries should attempt sincerely to cultivate Islamic spirit in the Muslim community. Zakat would eradicate the unused savings, prevent wealth accumulation, and appeal investments. For there is no guarantee that realized savings would be invested. Investments would only possibly be raised if the opportunity of investments from various grades of risks and a variety of time limit is available with life and property security, the assurance made to prevent arbitrary nationalization and asset taking over, a normal grade of tax, and relative stability in internal and external values in the currency of the country (Suprayitno 2005).

Islamic norms would be considered as giving the positive impact on investments by assuming that this change would really happen and that appropriate circumstance of investments is really exist. Profit sharing based on fair dividends between the capital and the entrepreneur would direct the allocation of resources efficiently. By diminishing one of main resources from uncertainty and unfairness influencing the decision of investment, the entrepreneur would easily make the decision. Transforming "a saver to be an entrepreneur" (as in Ingo Karsten's terms), would bring business risks distributed evenly, by restoring the investment climate (Sulaiman, 1985).

\section{Nisab of Zakat}

Nisab (the minimum compulsory measurement) of zakat in economic terms is as follow (Suprayitno):

$Z_{1}=$ levy of zakat from the household

$Z_{2}=$ levy of zakat from each company is $2.5 \%$

$Z=$ total levy of zakat $Z=Z_{1}+Z_{2}$ 
$Y=$ national net of income,

$Y=Y_{1}+Y_{2} . Y_{1}$ is net income from the household and $Y_{2}$ is net income of the company.

$\mathrm{N}_{1}=$ Nisab from the household. It is a function of national income, when $\mathrm{N}_{1}$ depends on the basic needs and level of price and the proportion is firmed in an income.

$\mathrm{N}_{2} \quad$ = Nisab from the company. It is also a function of national income, when the proportion of $\mathrm{N}_{2}$ is firmed in an income, but its value is coming from the capital labor and the capital decrease.

$R(Y)=$ a total income of a company is the function of $R(Y)=d Y-C(Y)$

$C(Y)=$ a total cost of production.

$A=$ constant

$Z=Z_{1}+Z_{2}$

$=t\left[A . Y t-\left(N_{1}\left(Y_{1}\right)+\left(N_{2}\left(Y_{2}\right)\right)-C\left(Y_{2}\right)\right]\right.$

$=t\left[A \cdot Y t-\left(N_{1}\left(Y_{1}\right)+B . Y_{2}-N_{2}\left(Y_{2}\right)\right)\right]$

If zakat levied from the net income of the household could be optimal, there would be the following equals:

$\mathrm{dZ} / \mathrm{d} Y_{1}=0$

$=A-N_{1}$

When zakat levied optimally on the net income of a company, there would be the following equals:

$\mathrm{dZ} / \mathrm{d} \mathrm{Y}_{2}=0$

$=\mathrm{B}-\mathrm{N}_{2}$

Therefore it is concluded that

$\mathrm{N}_{1}{ }^{\prime}+\mathrm{N}_{2}{ }^{\prime}=\mathrm{A}+\mathrm{B}=$ constant

The explanation of equals (2) and (3) is the overlap that might happen between $\mathrm{N}_{1}$ and $\mathrm{N}_{2}{ }^{\prime}$ (as a main indicator of difference with the existence of income)

Firstly, the record that $Z=a . Y$, where ' $a$ ' is positive and firmed (2.5\%). So, by the existence of the increase of income, the zakat would also raise as big as 'a' assuming that the other is firmed, not as a function of exponent, used to reduce real incomes and expenses. This alternative could be seen from the fact that the amount of zakat is fixed as $2.5 \%$ from the accumulation of wealth and net income in the period of 1 year.

Secondly, if $Y$ is increased $N_{1}$ and $N_{2}$ move against each other. When the level of nisab is its value as much as the level of net income, if $\mathrm{N}_{1}$ is in the lower level so $\mathrm{N}_{2}$ is in the higher level.

\section{Essence of Distribution of Zakat}

Zakat in its various form has a function to develop levy of nation's wealth, for it reproduces all kinds of existing wealth. Not as in the modern tax, the arrangement of zakat collection is so simple and it requires no special knowledge whatsoever. The performance of zakat collection as it should be, economically, could erase the gap of blatant economic wealth, and could also redistribute evenly, and could help to control the rapidity of inflation. Besides the uncertain development of the distribution of money in the domestic domain, the lack of goods and the acceleration of the distribution of money, distribution of wealth unevenly could also bring the rapidity of inflation and the devastation of market.

In this case, zakat is not a substitution from various models of self-financing made by modern society to provide social insurance protection for unemployment, accident, aging, and handicap by 
reducing the wages of employees and from the contribution of working. Also, zakat does not replace the components of government expenses for prosperity and for aiding in the time of disaster affirmed in the government's budget. Nevertheless, zakat could be a support or supplement to reduce government's burden to create redistribution and diminishing poverty. In addition, zakat does not prevent the state to adopt fiscal sizes, retributive schemes, and broadening employment, and creating self-endeavor through soft-loans from the zakat funds itself (Suprayitno 2005).

Zakat is an independent social security instrument employing the rich having a moral responsibility to aid the unfortunate and neglected to help themselves by any means of social security schemes, so that destitution and poverty could be eradicated in the Muslim society.

\section{Payment of Zakat}

There is a strong relationship between the acceptance and the payment of zakat, but it happens through changes in the market influencing the income and profitability. However, there is a stable inclination in all price changes in Islamic economy. Such price movement could influence level or grade of nisab, and through the "zakatable" level could influence net income of the household. Now we could see how it is solved (Suprayitno 2005):

If

$$
\begin{aligned}
& N_{1}=a_{1}+b_{1}(p \cdot B) \\
& N_{2}=a_{2}+b_{2}(p \cdot B+l)
\end{aligned}
$$

where:

$B=$ is the amount of the Basic needs

$P=$ is the Price of the basic needs

$\mathrm{I}=$ is the production/reduction of other investment and capital labor for the company where the level of its nisab as much as $\mathrm{N}$

$Y_{1}=$ is the net income of the household

$Y_{2}=$ is the net income of the company

$Y=Y_{1}+Y_{2}$

$a_{1}, a_{2}, b_{1}$, and $b_{2}$ is the next coefficient value

$$
\begin{array}{ll}
N_{1}= & b_{1}(p \cdot d B / d Y) \\
N_{2}= & b_{2}(p \cdot d B / d Y m+d l / d Y)
\end{array}
$$

As in the previous equals that $\mathrm{N}_{1}+\mathrm{N}_{2}=$ constant, so

$$
b_{1}(p \cdot d B / d Y)+b_{2}(p \cdot d B / d Y)=\text { constant. }
$$

Next, in the determined level of price, when B raise/increase, I would lower or decrease, by an increase of income and the reverse. Such relationship is similar to those giving earlier between $\mathrm{N}_{1}$ and $\mathrm{N}_{2}$. An increase in demand for basic needs requires the demands for dividend to be money is higher, and this is in the direction to reinvest is lower than the hold income and a bigger need for external finance (Rosyidi, 2006).

Now, consider $p$ with different value. $p$ could stabilize the decrease on the side of consumer's prosperity of the household. Then, by lower $p, d B / d Y>0$. It is showed by the shift of $B-I$ curve bending along $A_{1}, A_{2}, A_{3}$ etc. in the following figure. On the other hand, if $p$ raise/increase $d B / d Y$, it would profit the producer. It is showed by the shift of $B-I$ curve bending along $B_{1}, B_{2}$, $B_{3}$, etc. The 
change of different price would bring an optimal increase along $B$ and I showed by $a_{0}, a_{1}, a_{2}$, etc. and $b_{0}, b_{1}, b_{2}$, etc.

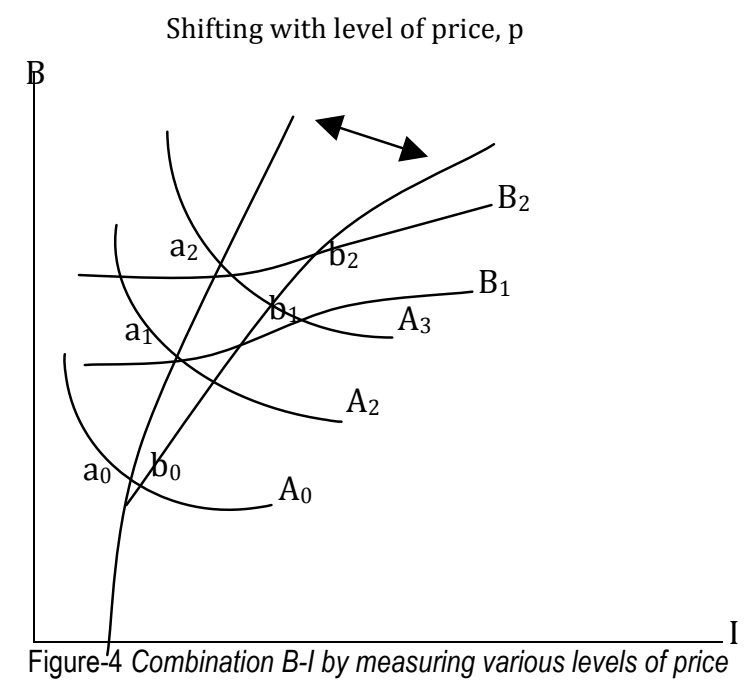

Now we could see that from various lines by measuring various price changes would be determined the optimal lines. To prove this, the following Figure- 5 shows the relationships of each $B-I$ curve by a price change in the previous figure (Figure-4) there is a total allocation of zakat collection between the household $\left(Z_{1}\right)$ and the company $\left(Z_{2}\right)$, where allocation of these $Z_{1}-Z_{2}$ should be in line with the curve showed by $O A$ and $O B$, and the like/similar.

The reason of cutting the curve such as (that) is that no one [concerning] merely two sectors could influence the increase of zakat payment when the price is changed specifically. Such overlapping dots as a, b, etc. describing an optimal line to the total allocation of zakat between the household and the company (Suprayitno 2005 dan Sulaiman 1985).

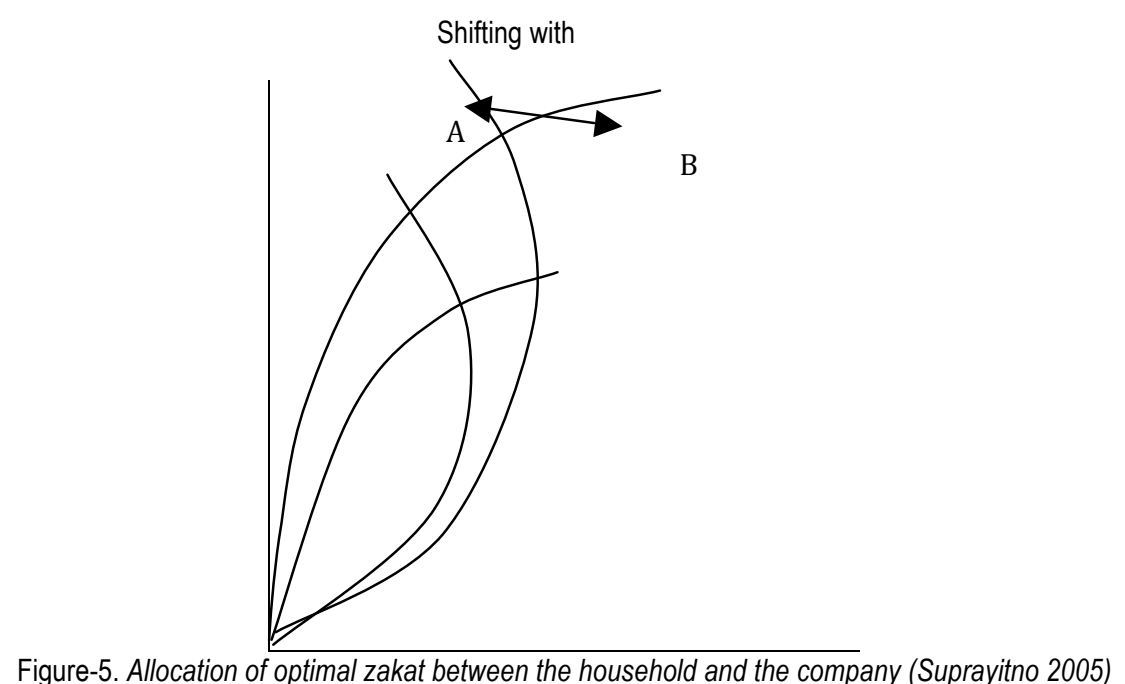

5. Goal of Zakat Management: Indonesian Cases (ash-Shawi dan al-Mushlih, 2001)

Zakat would urge investments directly or indirectly. Directly, by enforcing zakat to the wealth, the saved wealth would be activated or invested. Indirectly, by raising the consumption of basic goods and services as the effect of the increase of income of the poor because of zakat, the demands of 
basic goods and services would also increase. This increase of goods and services would attract the production of basic goods and services. Among the goals and targets of zakat are as follow (Eko Suprayitno and Shalah ash-Shawi \& Abdullah al-Mushlih):

\section{a. Renovating the Quality of Life}

The main objective of zakat is to renovate the quality of life of the people. There are many Indonesian people who still under the line of poverty, and because of that there are such serious problems as education and health, which are hard to be solved. To this, there are two kinds of activities. Firstly, such activities as motivation by giving knowledge on management (in a simple way), giving a guidance, training skills on some kinds of "home industry", etc. Secondly, activities creating capital matters, either by money as the first capital, injection of capital, or the capital of goods such as equipments, cattle, etc. In short, the enforcement of zakat is in the frame of restoring the quality of life of the followings:

\section{1) Small scale farmers and farming workers}

In Indonesia, this group is the majority. In order to elevate their quality of life, the enterprise should be done firstly is giving them the knowledge on "home industry." It is about enterprise relating closely to their environment. It means that by the knowledge they are expected to create their own endeavor to increase their income. Also, there should be capital to initiate their venture such as money (for enterprise) or cattle (goats, cows or buffaloes, etc.)

\section{2) Fishermen}

Most of our fishermen still use traditional equipments and that their quality of life is under the line of poverty. Even if they use motor-ship, generally they hire it or even they are only as workers at the ship. Those fishermen should be given the capitals either as equipments (to catch fish) or helping their marketing.

\section{b. Retailers/Small-scale enterprise managers}

In order that retailers or other small-scale industries developed in line with their reasonable needs, there should be attempts such as: (1) giving them the knowledge on management and guiding them so that they could manage their endeavors well; and (2) giving them the capital to develop their endeavors.

\section{c. Education and Scholarship}

Some religious scholars (ulama) and Muslim intellectuals suggest zakat as an eternal fund for scholarship. Usually the condition of Islamic educational institutions such as madrasah (religious schools) especially the private ones are not good at all. It is because of the lack of financial support to develop and maintain buildings, to provide qualified teachers, to manage planned curriculum, etc. Besides, another problem faced by Muslim community is their social life which is still far from enough, so that their children could not continue their education. These problems should be answered by certain concepts and programs in enforcing the function of zakat, as being required by Islamic doctrines. In this case the programs being performed in essence could be differentiated into two. Firstly, giving aid to the organizations or foundations of education whether it is formed as money the management of which is released fully to the managers or as educational equipments urgently needed by them. Such aid could be given incidentally as a plea for self- 
improvement or routinely to develop the quality of education. Secondly, giving scholarship to certain students, so that they could continue their education as what being termed by the managers of the Board of Zakat Management (Badan Amil Zakat, BAZ).

\section{d. Solving the Problems of Labor and Unemployment}

Another activity by zakat fund is solving the problems of labor and unemployment. Lately, these problems are hard to be solved. The labor age around 60 millions of people could not be absorbed by the existing opportunity of work. The targets of this preliminary project are the destitute (fuqara), that is, those who have not any fixed job to fulfill their own daily needs. It is also addressed to the drops-out, students who have finished their education or those who have their own job but their endeavors are stagnant, or collapsed because of the lack of capital support. This financial support could be given to the individuals or the groups based on their prospective knowledge.

\section{e. Program of Health Services}

The program of health services for the poor and for those who live in the rural areas should be solved by the enforcement of zakat. As a social concept, zakat could be used as service to the prosperity of Muslims, including their health. The usage of zakat in this sense could be perceived as the interpretation of "Fisabilillah" meaning as public interests as understood by most ulama.

\section{f. Orphanage}

The efforts to handle such neglected children as orphans had been done either by the government or private organizations or institutions, in urban or in rural areas. Such endeavors are humanitarian and become one of Islamic doctrines (to rear and educate the orphans). Here, then, Muslims should be more responsible for taking care of the orphans, for it is a kind of worship to Allah SWT ('ibadah). It could be done individually in every Muslim household or in some organizations which could gather the orphans in a massive scale. Generally the problems in rearing the orphans are involving any process of bringing the orphans to be independent, to be useful for the society, the country, and the religion.

\section{CONCLUSION}

This explanation of zakat in the light of Prahalad's ideas hopefully could open our horizons. The present writer surely believes that it is far from being perfect. Nevertheless, the first steps to synergize ideas or inter-ideas for the sake of economic improvement should be done promptly. In Islamic economics, or even in Islamic teaching itself, even the first mission of Muhammad [p.b.u.h.] in the period of Mecca is to free the society from the poverty (Q.S. Al-Balad:6), without differentiating races, tribes, nations, and even religions. And the Prophet himself reportedly says, "the best humans are those who are the most they could give benefit to other humans" [khair alnas anfa'uhum li al-nas]. 


\section{References}

Abdul Muhsin Sulaiman, Thahir. (1985). Menanggulangi Krisis Ekonomi Secara Islam, translated into Indonesian by Anshori Umar Sitanggal. Bandung: Al-Ma'arif.

C.K. Prahalad, (2005). The Fortune at the Bottom of the Pyramid. Pennsylvania: Wharton School Publishing.

Harun Nasution, (1990). Teologi Islam. Jakarta: UI-Press.

Joseph E. Stiglitz, (2000). Economics of the Public Sector. New York/London: W.W. Norton \& Company.

Kuncoro, Mudrajad. (2006). Ekonomika Pembangunan. Yogyakarta: UPP-STIM YKPN.

M.L. Jhingan, (2007). The Economics of Development and Planning, translated into Indonesian by D. Guritno. Jakarta: Rajawali Press.

Muhammad b. 'Ali b. Muhammad Al-Syawkani. (2007 M/1428 H). Fath al-Qadir,. Beyrut: Dar alMa'rifah.

Nasution,Harun. (1995). Islam Rasional. Jakarta: Rajawali Press,

P. Todaro, Michael \& C. Smith, Stephen. (2006). Economic Development, translated into Indonesian by Haris Munandar. Jakarta: Erlangga.

Rosyidi, Suherman. (2006). Pengantar Teori Ekonomi. Jakarta: Rajawali Press,

Shalah ash-Shawi \& Abdullah al-Mushlih. (2001). Fikih Ekonomi Keauangan Islam. Jakarta: Darul Haq.

Suprayitno, Eko. (2005). Ekonomi Islam. Yogyakarta: Graha IImu.

Wirasasmita, Yuyun. (2010). "Economic Development", paper presented at DET Programme seminar of Development Economic, at Padjadjaran University. 